\title{
Successful pulmonary valve regurgitation and pulmonary artery dilatation repair as a reintervention of pulmonary stenosis after 45 years
}

\author{
I Duvan*, S Ates, M Kurtoglu, BE Onuk, P Sungur, IS Karacan \\ From 23rd World Congress of the World Society of Cardio-Thoracic Surgeons \\ Split, Croatia. 12-15 September 2013
}

\section{Background}

Pulmonary Regurgitation (PR) accompanying with pulmonary artery dilatation is one of the most common complications after pulmonary valve stenosis repair during the late follow up period. PR is well tolerated first, but later it becomes the reason of the right ventricular dilatation and the morbid effects of it. Decision in the time of performing PVR is vitally important because severe PR ends up with RV volume overload and PVR is shown to be capable in reducing it and ameliorating the systolic activity afterwards. On the other hand PVR should have been performed as late as possible because of its limited time of life.

\section{Methods}

A 57 year old man that underwent an operation of pulmonary comissurotomy for pulmonary stenosis and ASD closure 45 years ago admitted our clinic with the symptoms of congestive heart failure such as dyspnea, peripheral edema and oliguria. Hypertension, DM, hyperlipidemia, smoking and coronary artery disease were the other remarkable points of his medical past. He was hospitalised for a stent implantation of RCA in 2009 and because of atrial fibrillation due to congestive heart failure in 2011. Cardiac MRI findings were; severe PR, $48 \mathrm{~mm} \mathrm{PA}$, $101 \times 76 \times 60 \mathrm{~mm} \mathrm{RV}, 79 \times 53 \times 56 \mathrm{~mm} \mathrm{LV}$ and EF was $34.6 \%$. Right and left ventriculography revealed that RVP and PAP were $35 \mathrm{mmHg}$ whereas PCWP was $24 \mathrm{mmHg}$. RCA had a lesion of $50 \%$ proximally and posterobasal akinesia in $\mathrm{LV}$.

\section{Results}

PVR (25 no Medtronic Bioprothesis Valve), Pulmonary Artery Aneurysmorrhaphy, CABGX1 and Tricuspid Kay

* Correspondence: ibrahimduvan@hotmail.com

Department of Cardiovascular Surgery, Güven Hospital, Ankara, Turkey
Annuloplasty was performed. Aortic clamp time was $119, \mathrm{CPB}$ time was 164 and the operation time was 330 minutes. Intubation period was 14 , ICU stay was 46 hours, no $(+)$ inotrope support was needed and he was discharged on the 6th day after.

\section{Conclusion}

PVR and PA Aneurysmorrhaphy was performed successfully as a reintervention in this case for severe PR and PA dilatation, occurred in the late follow up period of pulmonary comissurotomy.

Published: 11 September 2013

\section{doi:10.1186/1749-8090-8-S1-P103}

Cite this article as: Duvan et al:: Successful pulmonary valve regurgitation and pulmonary artery dilatation repair as a reintervention of pulmonary stenosis after 45 years. Journal of Cardiothoracic Surgery 2013 8(Suppl 1): P103.

Submit your next manuscript to BioMed Central and take full advantage of:

- Convenient online submission

- Thorough peer review

- No space constraints or color figure charges

- Immediate publication on acceptance

- Inclusion in PubMed, CAS, Scopus and Google Scholar

- Research which is freely available for redistribution

Submit your manuscript at www.biomedcentral.com/submit C) Biomed Central 